\title{
Phytoseiidae (Acari) in forest fragments in the State of São Paulo, Brazil
}

\author{
PETERSON R. DEMITE ${ }^{1}$, ANTONIO C. LOFEGO ${ }^{2,3}$ \& REINALDO J. F. FERES ${ }^{2,3}$ \\ ${ }^{1}$ UNESP-Universidade Estadual Paulista, PPG - Biologia Animal, São José do Rio Preto, SP, Brazil. \\ E-mail: peterson_demite@yahoo.com.br \\ ${ }^{2}$ UNESP-Universidade Estadual Paulista, Depto. de Zoologia e Botânica, São José do Rio Preto, SP, Brazil. \\ E-mail: aclofego@ig.com.brand reinaldo@ibilce.unesp.br \\ ${ }^{3} \mathrm{CNPq}$-Brazil Researcher
}

\begin{abstract}
Mites of the family Phytoseiidae have been extensively studied as biological control agents of various pests. However, knowledge of these mites in plants of forest fragments in Brazil is still incomplete. The aim of this study was to study the occurrence of Phytoseiidae in forest fragments in the Northwestern of State of São Paulo. Samplings were collected from 18 forest fragments, including 102 plant species belonging to 47 plant families. We recorded 46 phytoseiid species belonging to 17 genera and three subfamilies. Two new species are described, Amblyseius biotafapesp sp. nov. and Amblyseius novagranadensis sp. nov. Trichilia casaretti and Actinostemon communis harbored the largest numbers of species, 29 and 22, respectively. Some species recorded in this study have been frequently reported on cultivated plants. Besides the biological importance of knowing the phytoseiid mite fauna in these forests, survey studies can provide information to support projects on integrated pest management.
\end{abstract}

Key words: Conservation, diversity, native plants

\section{Introduction}

Phytoseiid mites have received considerable worldwide attention because of their potential as natural enemies of phytophagous mites (McMurtry, 1984), since all phytoseiid species are predators, with varying levels of specificity (Gerson et al., 2003). Phytoseiidae is one of the most extensively studied families of mites, with about 2,300 species in the world (Chant \& McMurtry, 2007). However, knowledge about these mites in some areas is still incomplete. Only in the last five years, 18 species of Phytoseiidae have been described from Brazil (Lofego \& Feres, 2006; Demite et al., 2007, 2008a, b; Ferla \& Silva, 2008, 2009, 2011; Lofego et al., 2009, 2011a, b; Ferla et al., 2010; Kreiter \& Tixier, 2010; Souza et al., 2010; Mineiro et al., 2011).

Earlier studies in Brazil largely reported the occurrence of phytoseiids in various crops, like citrus, coffee, rubber trees, and others, (e.g. Pallini Filho et al., 1992; Sato et al., 1994; Ferla \& Moraes, 1998; Feres, 2000; Collier et al., 2004; Hernandes \& Feres, 2006; Mineiro et al., 2009). However, until recently, studies of mites and other arthropods in natural vegetation were not a priority for many institutions and research funding agencies in Brazil (Moraes et al., 2001). Studies of diversity of mites in forest fragments are especially important in areas that suffer or have suffered great human influence. In recent years, surveys of mites were conducted in forest fragments in State of São Paulo (Feres \& Moraes, 1998; Gondim Jr. \& Moraes, 2001; Zacarias \& Moraes, 2001; Arruda Filho \& Moraes, 2002, 2003; Feres et al., 2005; Lofego et al., 2004; Oliveira et al., 2005; Buosi et al., 2006; Castro \& Moraes, 2010). The State of São Paulo currently has approximately $14 \%$ of its original vegetation (SMA/IF 2005), composed of Mata Atlântica (68\%) and Cerrado (32\%) (or Brazilian Atlantic Forest and Brazilian Savannah, respectively). These biomes were considered by Myers et al. (2000) as hotspots, areas of world conservation priority due to great concentration of endemic species. Thus, the aim of this study was to report the occurrence of Phytoseiidae in forest fragments in the Northwestern of the State of São Paulo. 